\title{
Ecological Analysis of Success of TB Treatment and Its Related Factors in Indonesia in 2019
}

\author{
Alfons Deristo Lega ${ }^{1}$, Hario Megatsari ${ }^{1}$, Shrimarti Rukmini Devy ${ }^{1}$ \\ ${ }^{1}$ Faculty of Public Health, Universitas Airlangga, Surabaya, Indonesia
}

\begin{abstract}
Background: Tuberculosis is a direct infectious disease caused by TB germs (Mycobacterium Tuberculosis). Indonesia is ranked third in the world, with the largest incidence of tuberculosis after China and India, with 845,000 cases or $315 / 100,000$ in 2019 . The study was intended to analyze the coverage of treatment of all cases, the percentage of poor people by province and the ratio of public health centre per sub-district in the province to the success of tuberculosis treatment in all provinces in Indonesia in 2019.

Methods: The ecological approach is carried out using secondary data from the Ministry of Health of the Republic of Indonesia in the form of Health Profile of the Republic of Indonesia in 2019 and Data and Information: Health Profile of Indonesia in 2019. Data from 34 provinces in Indonesia related to the success rate of TB treatment, the coverage of treatment of all TB cases, the percentage of poor people by province and the ratio of public health centre per sub-district in the province using cross tabulation.

Results: The results showed that the success rate of TB treatment in Indonesia in 2019 was in the moderate category in line with the coverage of all TB cases, the percentage of poor people by province and the ratio of puclic health centre per sub-district in the province which is also in the moderate category.

Conclusion: Efforts to monitor and record cases and treatment of TB patients need to be improved to improve TB treatment coverage. Improving the economy of the community and equalizing the availability of public health centre are also very important to improve the success of TB treatment.
\end{abstract}

Keywords: ecological analysis, TB Treatment, Tuberculosis, secondary data.

\section{Introduction}

Tuberculosis is a direct infectious disease caused by TB germs (Mycobacterium Tuberculosis). Most TB germs attack the lungs, but can also attack other organs. (1) Tuberculosis is one of the top 10 causes of death worldwide and is the leading cause of death from one of the infection agents ranked above HIV/AIDS.(2)

Nationally one of the diseases that is quite high in Indonesia is tuberculosis, and when compared to

\section{Corresponding Author:}

Hario Megatsari

Email: hario.megatsari@fkm.unair.ac.id other countries, Indonesia is among the countries that have many tuberculosis sufferers.(3) The number of notifications of tuberculosis (CNR) cases or the number of all cases of tuberculosis treated and reported per 100,000 inhabitants during 2016-2018 increased by 139 in 2016, 169 in 2017 and 214 in 2018.(4)

Indonesia is currently ranked third in the world, with the largest incidence of tuberculosis after China and India.(5) In 2019 the total incidence of tuberculosis in Indonesia was 845,000 cases or $315 / 100,000$ inhabitants.

(2) Meanwhile, based on RPJMN (medium-term development plan) contained in Presidential Regulation No. 59 of 2017 concerning SDGs set a target of tb prevalence in 2019 to $245 / 100,000$ residents.(6) 
If referring to WHO's target for indicators of treatment success rate of $85 \%$, then nationally the success rate of tuberculosis treatment has been achieved in 2019 which is $86.6 \%$.(4) While the ministry of health sets the success rate of treatment of all cases at least $90 \%$.(7) so that if considered achievement per province, there are only 9 out of 34 provinces that have reached the national target with the success rate of tuberculosis treatment or achievement is above the figure of $90 \%$.

Based on the description of the problem, the study aims to analyze the factors of treatment coverage of all cases, the percentage of poor people by province and the ratio of public health centre per sub-district in the province to the success of tuberculosis treatment in all provinces in Indonesia in 2019. Ecological approach is used in this research in order to provide a trend of the situation throughout Indonesia so that it can be used as the basis for future policies. The study also aimed for all the authors (researcher, scientist, research scholar, professor, tutor, assistant / associate professor etc).

\section{Materials and Methods}

\section{Study Design}

This research is an ecological analysis study using secondary data. The data analyzed are aggregated data on a specific group or level, which in this study is the provincial level. Variables in ecological analysis can be aggregate measurements, environmental measurements, or global measurements. $(8,9)$

\section{Data Sources}

The study was conducted using secondary data sourced from "Data and Information: Indonesia Health Profile year 2019" and "Indonesia Health Profile 2019" issued by the Indonesian Ministry of Health. The data is available at the link of www.pusdatin.kemkes.go.id, the analysis unit in this study is all provinces in Indonesia. In total (total sampling) 34 provinces were analyzed in this study.

\section{Data Analysis}

The main variable that will be predicted is the "Success Rate of TB Treatment", which is the number of all cured tuberculosis cases and those receiving complete treatment among all treated and reported tuberculosis cases. Variable predictors consist of the coverage of treatment of all cases, the percentage of the poor people by province and the ratio of public health centre per subdistrict in the province. Each variable will be categorized into 3 strata with the same points pieces statistically. The data is descriptively analyzed by cross-tabulation.

The dependent variable in this study was the success rate of TB treatment. In addition to the success rate of TB treatment as dependent variables, there are 3 independent variables analyzed in this study which is the coverage of treatment of all cases, the percentage of poor people by province and the ratio of public health centre per sub-district in the province.

Data were analyzed by univariate and bivariate analysis. Bivariate analysis was performed using crosstabulations. The entire analysis process utilizes SPSS 21 software.

Table 1. Data Sources of ecological Analysis of TB Treatment Success Rate in Indonesia in 2019

\begin{tabular}{|c|c|c|}
\hline \multirow{2}{*}{ Sources } & Type of Variables & Name of Variables \\
\hline \multirow{2}{*}{ Indonesia Health Profile in 2019 } & Dependent & The Success Rate of TB Treatment \\
\cline { 2 - 3 } & Independent & The coverage of treatment of All cases \\
\cline { 2 - 3 } & Independent & The Percentage of Poor People by Province \\
\hline $\begin{array}{c}\text { Data and Information: Indonesia } \\
\text { Health Profile in 2019 }\end{array}$ & Independent & $\begin{array}{c}\text { The Ratio of Public Health Centre Per sub-district in the } \\
\text { province }\end{array}$ \\
\hline
\end{tabular}




\section{Ethical Approval}

The study was conducted by utilizing secondary data from published reports. For this reason, ethical clearance is not required in the implementation of this study.

\section{Results and Discussions}

This study is an ecological study that focuses on comparisons between groups. The groups analyzed in this study were 34 provinces in Indonesia with an average of success rate of TB treatment is $84.42 \%$. When referring to the target set by the Ministry of Health's RENSTRA of $85 \%$, a total of 20 provinces in Indonesia have reached the target and 14 provinces have not reached the target. Three variables related to the
Medico-legal Update, October-December 2021, Vol.21, No. $4 \mathbf{8 3}$ success rate of TB treatment analyzed in this study are the coverage of treatment of all cases, the percentage of poor people by province, and the ratio of public health centre per sub-district in provinces in Indonesia.

Table 2 shows the statistical descriptions of the success rate of TB treatment and the predictor variables in Indonesia. The success rate of $\mathrm{TB}$ treatment in Indonesia in 2019 with mean was $84.42 \%$, but there are still some provinces with the the minimum value or the lowest percentage among others, there are Maluku 58.7\%, West Papua 41,5\%, and Papua 68.7\%. And the province with highest success rate of TB treatment is Lampung province (97.3\%).

Table 2. Statistical Description of Variables Related to Success Rate of TB Treatment in Indonesia in 2019.

\begin{tabular}{|c|c|c|c|c|}
\hline & $\begin{array}{c}\text { The Success Rate } \\
\text { of TB Treatment }\end{array}$ & $\begin{array}{c}\text { The coverage of } \\
\text { treatment of All } \\
\text { cases }\end{array}$ & $\begin{array}{c}\text { The Percentage } \\
\text { of Poor People } \\
\text { by Province }\end{array}$ & $\begin{array}{c}\text { The Ratio of Public Health Centre } \\
\text { Per sub-district in The Province }\end{array}$ \\
\hline N & 34 & 34 & 34 & 1.5779 \\
\hline Mean & 84.424 & 56.329 & 10.4550 & 1.4100 \\
\hline Median & 86.800 & 53.050 & 8.7600 & 1.36 \\
\hline Mode & 89.4 & 36.6 & 3.47 & 1.03104 \\
\hline Std. Deviation & 10.6954 & 17.2772 & 5.68287 & 1.063 \\
\hline Variance & 114.391 & 298.500 & 32.296 & 6.88 \\
\hline Range & 55.8 & 62.2 & 24.06 & 0.28 \\
\hline Minimum & 41.5 & 34.0 & 3.47 & 7.16 \\
\hline Maximum & 97.3 & 96.2 & 27.53 & \\
\hline
\end{tabular}

Source: Indonesia Health Profile in 2019 dan Data and Information: Indonesia Health Profile in 2019

Table 3 shows the result of cross-tabulation by the coverage of treatment of all cases with success rate of TB treatment in Indonesia as dependent variable. Based on Table 3 it is known that in the low category of the coverage of treatment of all cases $(\leq 54,73)$ seen dominated by the number of tb treatment in the moderate category $(60,2-78,8)$ in 4 provinces. While in the moderate category of the coverage of treatment of all cases (54.74-75.47) is dominated by the success rate of TB treatment in the moderate category (60.2-78.8) which is 21 provinces. Then the coverage of treatment of all cases in the high category $(\geq 75.48)$ seems to also 
be dominated by the success rate of TB treatment in the moderate category (60.2-78.8) as many as 5 provinces.

Table 3. Cross-Tabulation result the coverage of treatment of all case and the Success Rate of TB Treatment in Indonesia in 2019

\begin{tabular}{|c|c|c|c|c|c|c|}
\hline \multirow{3}{*}{$\begin{array}{l}\text { The coverage of } \\
\text { treatment of All cases }\end{array}$} & \multicolumn{6}{|c|}{ The Success Rate of TB Treatment } \\
\hline & \multicolumn{2}{|c|}{$\begin{array}{c}\text { Low } \\
(\leq 60,1)\end{array}$} & \multicolumn{2}{|c|}{$\begin{array}{c}\text { Moderate } \\
(60,2-78,8)\end{array}$} & \multicolumn{2}{|c|}{$\begin{array}{c}\text { High } \\
(\geq 78,9)\end{array}$} \\
\hline & $\mathrm{n}$ & $\%$ & $\mathrm{n}$ & $\%$ & $\mathrm{n}$ & $\%$ \\
\hline $\begin{array}{c}\text { Low } \\
(\leq 54,73)\end{array}$ & 0 & 0 & 4 & 13.3 & 0 & 0 \\
\hline $\begin{array}{c}\text { Moderate } \\
(54,74-75,47)\end{array}$ & 3 & 100 & 21 & 70.0 & 1 & 100 \\
\hline $\begin{array}{c}\text { High } \\
(\geq 75,48)\end{array}$ & 0 & 0 & 5 & 16.7 & 0 & 0 \\
\hline Total & 3 & 100 & 30 & 100 & 1 & 100 \\
\hline
\end{tabular}

Source: Indonesia Health Profile in 2019

The coverage of treatment of all TB cases is the number of all cases of tuberculosis treated and reported among the estimated number of all new cases of tuberculosis.(4) Based on the findings, this study shows that most provinces in Indonesia with success rates of TB treatment in the moderate category over with the coverage of treatment of all cases in the moderate category. Based on the previous study concluded that the treatment of TB cases in this case the history of treatment, can be used as a predictor of the success of TB treatment.(10) Other study have concluded that there is a relation between routine treatment and the success of TB treatment in children.(11)

In this study, there were also other factors besides the coverage of treatment of all TB cases that can determine the success rate of TB treatment. Therefore, it is necessary to know other factors besides the coverage of treatment of all cases that are also related to the success rate of TB treatment in Indonesia.

Table 4 shows the cross-tabulation result of the percentage of poor people by provinces with the success rate of TB treatment in Indonesia. Based on table 4 it is known that the percentage of poor people by province in low category $(\leq 11,49)$, is dominated by success rate of TB treatment in the moderate category $(60,2-78,8)$ which is 4 provinces. While in the moderate category of the percentage of poor people by province $(11,5-19,52)$ is dominated by success rate of TB treatment in moderate category $(60,2-78,8)$ which is 25 provinces. Then in the percentage of poor people by province in high category $(\geq 19,53)$ is dominated by success rate of TB treatment in low category $(\leq 60,1)$ as many as 3 provinces. 
Table 4. Cross Tabulation Result Percentage of Poor People by Province and The Success Rate of TB Treatment in Indonesia in 2019

\begin{tabular}{|c|c|c|c|c|c|c|}
\hline \multirow{3}{*}{$\begin{array}{l}\text { The Percentage of Poor } \\
\text { People by Province }\end{array}$} & \multicolumn{6}{|c|}{ The Success Rate of TB Treatment } \\
\hline & \multicolumn{2}{|c|}{$\begin{array}{l}\text { Low } \\
(\leq 60,1)\end{array}$} & \multicolumn{2}{|c|}{$\begin{array}{l}\text { Moderate } \\
(60,2-78,8)\end{array}$} & \multicolumn{2}{|c|}{$\begin{array}{l}\text { High } \\
(\geq 78,9)\end{array}$} \\
\hline & $\mathrm{N}$ & $\%$ & $\mathrm{~N}$ & $\%$ & $\mathrm{n}$ & $\%$ \\
\hline $\begin{array}{c}\text { Low } \\
(\leq 11,49)\end{array}$ & 0 & 0 & 4 & 13.3 & 0 & 0 \\
\hline $\begin{array}{c}\text { Moderate } \\
(11,5-19,52)\end{array}$ & 0 & 0 & 25 & 83.3 & 1 & 100 \\
\hline $\begin{array}{c}\text { High } \\
(\geq 19,53)\end{array}$ & 3 & 100 & 1 & 3.3 & 0 & 0 \\
\hline Total & 3 & 100 & 30 & 100 & 1 & 100 \\
\hline
\end{tabular}

Source: Indonesia Health Profile in 2019

This study shows that the percentage of poor people by province in Indonesia is in the moderate category, in line with the success rate of TB treatment which is also in the moderate category. This means that the more provinces with the percentage of poor people in the moderate and low categories, the more and more provinces with $\mathrm{TB}$ treatment success rates in the moderate and high categories. Based on the previous study concluded the importance of financial support for TB patients to improve TB treatment outcomes.(12) The other revious study results shows that there is a relation between poverty and tb patient delay in carrying out TB treatment.(13)
Table 5 shows the cross-tabulation result of the ratio of public health centre per sub-district in the province with the success rate of TB treatment. Based on table 5 , it is known that the ratio of public health centre per sub-district in the province in low category $(\leq 2,57)$ is dominated by the success rate of TB treatment in low category $(\leq 60,1)$ which in 1 province. While the ratio of public health centre per sub-district in the province in moderate category $(11,5-19,52)$ is dominated by the success rate of TB treatment in moderate category $(60,2-$ $78,8)$ which in 25 provinces. Then in high category of the ratio of public health centre per sub-district in the province $(\geq 4,88)$ is dominated by the success rate of TB treatment in moderate category $(60,2-78,8)$ which in 1 province. 
Table 5. Cross Tabulation Result Ratio of Public Health Centre per Sub-district in the Province and the Success Rate of TB Treatment in Indonesia in 2019

\begin{tabular}{|c|c|c|c|c|c|c|}
\hline \multirow{3}{*}{$\begin{array}{c}\text { The Ratio of Public Health } \\
\text { Centre Per sub-district in } \\
\text { province }\end{array}$} & \multicolumn{6}{|c|}{ The Success Rate of TB Treatment } \\
\hline & \multicolumn{2}{|c|}{$\begin{array}{c}\text { Low } \\
(\leq \mathbf{6 0 , 1 )}\end{array}$} & \multicolumn{2}{|c|}{$\begin{array}{c}\text { Moderate } \\
(60,2-78,8)\end{array}$} & \multicolumn{2}{|c|}{$\begin{array}{c}\text { High } \\
(\geq 78,9)\end{array}$} \\
\hline & $\mathrm{n}$ & $\%$ & $\mathrm{n}$ & $\%$ & $\mathrm{n}$ & $\%$ \\
\hline $\begin{array}{c}\text { Low } \\
(\leq 2,57)\end{array}$ & 1 & 33.3 & 0 & 0 & 0 & 0 \\
\hline $\begin{array}{c}\text { Moderate } \\
(2,58-4,87)\end{array}$ & 2 & 66.7 & 29 & 96.7 & 1 & 100 \\
\hline $\begin{array}{c}\text { High } \\
(\geq 4,88)\end{array}$ & 0 & 0 & 1 & 3.3 & 0 & 0 \\
\hline Total & 3 & 100 & 30 & 100 & 1 & 100 \\
\hline
\end{tabular}

Source: Data dan Information: Indonesia Health Profile in 2019

Public health centre is a health care facility that organizes public health efforts and first-level individual health efforts, with the priority of promotional and preventive efforts, to achieve the highest level of public health in its working area.(14) The ratio of public health centre per sub-district in province is defined as there is a minimum of 1 public health centre per 100,000 inhabitants in 1 province. While in this study, the ratio of public health centre per sub-district in the province in Indonesia shows that most provinces in Indonesia are in the moderate category, in line with the success rate of TB treatment which is also in the moderate category. Means that the higher the ratio of public health centre per sub-district in a province, the higher the success rate of TB treatment in the province. On previous research obtained results that the success rate of TB treatment in public health centre is higher than the success rate of TB treatment in hospitals.(15)

\section{Conclusions}

Based on the results of this study, it can be concluded that the success rate of TB treatment in Indonesia in 2019 is in the moderate category. This condition is in line with the treatment coverage of all TB cases, the percentage of poor people and the ratio of public health centre per sub-district in the province which is also in the moderate category. Efforts to monitor and record cases and treatment of TB patients must continue to be made to improve the scope of TB treatment. Improving the economy of the community and equalizing the availability of public health centre are also very important to improve the success of TB treatment.

Acknowledgments: The authors are grateful to the Ministry of Health of the Republic of Indonesia for providing a report, data and information as material for analysis in this study.

\section{Declaration of Conflicting Interests}

The authors declared no potential conflicts of interest with respect to the research, authorship, and/or publication of this article.

\section{References}

1. MINISTRY OF HEALTH RI. Technical Guidelines for Management and Management of TB in Children. KEMKES RI. Direktorat Jenderal Pencegahan dan Pengendalian Penyakit; 2016.

2. Global Tuberculosis Report. Global 
Tuberculosis Report 2020 [Internet]. Geneva: World Health Organization; 2020. Available from: https://apps.who.int/iris/bitstream/hand le/10665/336069/9789240013131-eng.pdf

3. Sembiring SPK. Indonesia Free - Tuberculosis. Sukabumi, Jawa Barat: CV Jejak, anggota IKAPI; 2019.

4. MINISTRY OF HEALTH RI. HEALTH PROFILE OF INDONESIA IN 2019. Jakarta: Kementerian Kesehatan Republik Indonesia; 2020.

5. MINISTRY OF HEALTHRI. Technical Instructions for Handling Tuberculosis Laternt Infections [Internet]. Jakarta: Direktorat Jenderal Pencegahan dan Pengendalian Penyakit, Kementerian Kesehatan RI; 2020. Available from: https://tbindonesia.or.id/ wp-content/uploads/2021/01/Isi-Juknis-ILTBFINAL-ok_published.pdf

6. Infodatin kemenkes RI. INFODATIN Tuberkulosis. 2018; Available from: https://pusdatin.kemkes. go.id/resources/download/pusdatin/infodatin/ infodatin-tuberkulosis-2018.pdf

7. Permenkes 67. REGULATION OF THE MINISTER OF HEALTH OF THE REPUBLIC OF INDONESIA NUMBER 67 OF 2016 CONCERNING TUBERCULOSIS PREVENTION. 672016 p. 163.

8. Morgenstern, H. Ecologic Studies in Epidemiology: Concepts, Principles, and Methods. Annual Review of Public Health. Vol. 16. 1995. 61-81 p.
9. Laksono, A. D., Kusrini, I. Ecological Analysis of Stunted Toddler in Indonesia. Indian Journal of Forensic Medicine \&Toxicology 14. 2020. 1685$1691 \mathrm{p}$.

10. Soeroto AY, Pratiwi C, Santoso P, Lestari BW. Factors affecting outcome of longer regimen multidrug-resistant tuberculosis treatment in West Java Indonesia: A retrospective cohort study. PLoS ONE [Internet]. 2021 Feb 8 [cited 2021 Mar 19];16(2). Available from: https://www.ncbi.nlm. nih.gov/pmc/articles/PMC7870080/

12. McNally TW, de Wildt G, Meza G, Wiskin CMD. Improving outcomes for multi-drug-resistant tuberculosis in the Peruvian Amazon - a qualitative study exploring the experiences and perceptions of patients and healthcare professionals. BMC Health Serv Res. 2019 Aug 22;19(1):594.

13. Datiko DG, Jerene D, Suarez P. Patient and health system delay among TB patients in Ethiopia: Nationwide mixed method cross-sectional study. BMC Public Health [Internet]. 2020 [cited 2021 Mar 24];20. Available from: https://www.ncbi.nlm. nih.gov/pmc/articles/PMC7368783/

14. Permenkes 75. Regulation of the Minister of Health of the Republic of Indonesia Number 75 of 2014. 752014 p. 24.

15. Ulya F, Thabrany H, Nadjib M, Junadi P. Cost effectiveness of interventions using the tb dots strategy in public healthcare and private hospitals in depok, west java, indonesia. Indian J Public Health Res Dev. 2019;10(9):1758-63. 